Biljana Nedeljković Beleslin ${ }^{1}$, Jasmina Ćirić, Miloš Stojanović, Mirjana Stojković, Slavica Savić, Tijana Lalić, Tanja Nišić, Marija Miletić, Miloš Žarković

\title{
INSULIN PULSATILITY AFTER THE INTRAVENOUS GLUCOSE BOLUS
}

Sažetak: CILJ: Cilj rada je da se proceni da li iznenadna promena koncentracije glukoze kod zdravih osoba dovodi do promene pulsatilne sekrecije glukoze slična onoj koja se nalazi kod obolelifh od diabetzes mellitusa tip 2 (T2D). DESIGN: Koncenpt studije je bio da se pankreas "resetuje" I i da se isprazne postojeće rezerve insulina, tako da se diskretne promene insulinske sekrecije mogu detektovati. METODE METHODS: Studija ej je uključila 6 kontrola I I 7 obolelih od T2D subjects. Krv za određivanje pulsatilne sekrecije insulina je uzorkovana na 2 minuta tokom 60 minuta. Bolus glukoze $(0.3 \mathrm{~g} / \mathrm{kg})$ je dat da bi se ispraznile rezerve insulina. REZULTATI RESULTS: Srednja koncentracija glukoze u T2D bila je značajno veća nekgo kod kontrola, ali se koncentracije insulina nisu razilkovale. Poluživot insulina, amplitida pulsa, broj i interval između pulsea se nisu razlikovali između grupa. ZAKLJUČAK CONCLUSIONS: Pulsatilna sekrecija insulina posle povećanja glikemje se ne razlikuje između zdravih i obolelih T2Ds. Međutim, defekt u insulinskoj sekreciji kod obolelih je prisutan, s obzirom na to da se ne luči dovoljno insulina kao odgovor na povećanu glikemiju.

Ključne reči: Insulin, Diabetes mellitus tip II, Pulsatilna sekrecija

Abstract: OBJECTIVE: The aim of the study was to assess whether sudden change in blood glucose concentration in healthy subject would produce insulin secretory pattern similar to one in type 2 diabetic subjects (T2D). DESIGN: The concept of the study was to "reset" the pancreas and empty the stored insulin pool, so that subtle derangements of the pulsatile insulin secretion could be studied. METHODS: The study group included 6 control and 7 T2D subjects. For insulin and glucose determination, blood was sampled for 60 minutes with 2 minutes intersample interval. To increase blood glucose an intravenous glucose bolus was given $(0.3 \mathrm{~g} / \mathrm{kg}$ body weight). RESULTS: The average glucose level

1 Biljana Nedeljković Beleslin, School of Medicine, University of Belgrade, Clinic of Endocrinology, Clinical Center of Serbia, biljana_beleslin@yahoo.com 
in the T2D group was significantly higher, but the average insulin concentration was not different between the groups. Insulin half-life, pulse amplitude, number of pulses and interpulse interval did not differ between the groups. CONCLUSIONS: Therefore, the sudden increase in blood glucose causes insulin secretory pattern to become similar in the healthy and in the T2D subjects. However, the defect in the insulin secretion or glucose sensing inherent to $\beta$-cell exists, as the insufficient quantity of insulin is secreted in response to the increased glucose level.

Key Words: Insulin, Type II Diabetes mellitus, Pulsatile secretion

\section{INTRODUCTION}

Regular oscillations are an inherent feature of the insulin secretion $(1,2)$. This oscillatory insulin secretion is altered in the type 2 diabetes (T2D), and in the insulin resistant states $(3,4,5,6)$. In T2D or insulin resistant subjects an increase in insulin sensitivity, or the overnight inhibition of insulin secretion leads to normalisation of the insulin secretory pattern, probably by repleating the immediately secretable insulin pool $(7,8)$. Results from the animal models of diabetes mellitus suggest that altered plasma insulin pattern could be due to the lower amplitude of insulin oscillations, rather then the alterations in their frequency $(9,10)$. In humans chronic changes in insulin sensitivity seem to have an effect on the insulin pulse frequency, while acute changes of factors that influence insulin secretion modify the insulin pulse amplitude $(11,12,13,14,8)$. Accordingly, sudden change in the blood glucose concentration would increase insulin pulse amplitude in healthy humans, and deplete the immediately secretable insulin pool. Consequently, the insulin secretory pattern in healthy subject would become similar to one in T2D subject. In addition, increased blood glucose level would amplify the insulin pulse amplitude making small amplitude pulses more amenable to detection. If the main determinants of the detected insulin secretory pattern are the size of immediately secretable insulin pool and the insulin pulse amplitude, then this pattern in healthy subject after sudden increase in blood glucose level should become similar to one in T2D. Therefore, the aim of this study was to assess whether sudden change in blood glucose concentration in healthy subject, would produce insulin secretory pattern similar to one in T2D subjects.

\section{SUBJECTS AND METHODS}

\section{Subjects}

Studies were performed in 6 healthy (control) and 7 T2D subjects. Diabetes was diagnosed according to American Diabetes Association criteria (15). Inclusion 
criteria for the control group (C) were: (i) body mass index (BMI) between 19 and $25 \mathrm{~kg} / \mathrm{m}^{2}$, (ii) normal oral glucose tolerance test, (iii) normal renal and liver function tests, (iv) no intercurrent disease in the last three weeks, (v) no signs of endocrine dysfunction, (vi) not taking any drugs, (vii) no history of diabetes mellitus in 1st degree relatives. Additional inclusion criteria for T2D subjects were: (i) negative urinary ketones, (ii) normal renal and liver function tests, (iii) no intercurrent disease in the last three weeks, (iv) no signs of other endocrine dysfunction, (v) not taking any drugs. T2D subjects were treated with diet alone or were newly diagnosed. The metabolic and clinical characteristics of the study groups are detailed in Table 1. A local ethical committee approved all studies. All subjects gave informed consent.

\section{TABLE 1.}

The metabolic and clinical characteristics of the study groups. Data are presented as median, minimum-maximum. ${ }^{*}$ Signifies statistically significant difference $(\mathrm{p}<0.05)$.

\begin{tabular}{l|cc} 
& Control & NIDDM \\
\hline \begin{tabular}{l|c} 
Age \\
(years)
\end{tabular} & 27 & 42 \\
$\mathrm{BMI}^{*}$ & $21-37$ & $31-61$ \\
$\left(\mathrm{~kg} / \mathrm{m}^{2}\right)$ & 21.81 & 29.58 \\
& $19.05-24.88$ & $21.61-34.08$ \\
Blood glucose* & & \\
$(\mathrm{mmol} / \mathrm{l})$ & 4.4 & 5.6 \\
& $3.6-5.4$ & $4.1-12$
\end{tabular}

\section{Study protocol}

Subjects were admitted to the Institute of Endocrinology, Belgrade School of Medicine. They consumed standardized isocaloric meals $(25-30 \mathrm{kcal} / \mathrm{kg})$, composed of $55 \%$ carbohydrate, $30 \%$ fat and $15 \%$ protein over the $48 \mathrm{~h}$ before the study. After a 12-h fast, blood was sampled for insulin determination. An indwelling venous catheter was placed in the antecubital vein. Sampling started at 08:00 $\mathrm{h}$, and lasted for $60 \mathrm{~min}$ with an intersample interval of $2 \mathrm{~min}$. Blood 
was collected using a plastic syringe and transferred to plain glass tubes. Heparin was not used. Before taking a blood sample, $0.2 \mathrm{ml}$ (catheter volume) was taken with another syringe and discarded. Immediately after the first blood sample was taken an intravenous glucose bolus was given $(0.3 \mathrm{~g} / \mathrm{kg}$ body weight, as the $50 \%$ glucose solution). The glucose samples were measured immediately after sampling, while insulin samples were frozen at $-20^{\circ} \mathrm{C}$ until assayed (the maximum freezing time was one week).

\section{Pulse analysis}

Pulse analysis was carried out using the PulsDetekt program that is based on the deconvolution of secretory and metabolic events. Details of the PulsDetekt program algorithm and validation were previously described $(6,8)$.

\section{Assays}

Glucose was determined using a Beckman glucose analyzer. The precision of the glucose determination was $0.17 \mathrm{mmol} / \mathrm{l}$. Insulin was determined using a radioimmunoassay (INEP, Zemun, Yugoslavia). All samples from one subject were processed in the same batch. The intra-assay coefficient of variation was $5.8 \%$.

\section{Statistical analysis}

Statistical analyses were done using the Mann-Whitney $\mathrm{U}$ test. The results are expressed as median, minimum-maximum. $\mathrm{P}$ values less than 0.05 were considered statistically significant.

\section{RESULTS}

During the study period the average glucose level in the T2D group was significantly higher than in the control group (T2D: 10.9, 9.0-17.5; C: 7.7, 5.0-9.8 mmol/1: $\mathrm{p}<0.01)$. However, the average insulin concentration was not different between the groups (T2D: 35.0, 4.4-72.6; C: 31.9, 9.2-60.0 mU/1: $\mathrm{p}=0.95$ ). Parameters obtained by the analysis of the pulsatile insulin secretion were not significantly different between the groups (table 2). 


\section{TABLE 2}

Characteristics of the pulsatile insulin secretion. Data are presented as median, minimum-maximum. There were no statistically significant differences.

\begin{tabular}{l|cc} 
& Control & NIDDM \\
\hline $\begin{array}{l}\text { Half life } \\
\text { (min) }\end{array}$ & 7.11 & 6.16 \\
$\begin{array}{l}\text { Number } \\
\text { of pulses }\end{array}$ & $5.57-10.07$ & $4.27-10.44$ \\
Interpulse interval & 9.5 & 6.0 \\
(min) & $5.0-11.0$ & $4.0-10.0$ \\
& 6.61 & 9.00 \\
$\begin{array}{l}\text { Pulse amplitude } \\
\text { (mU/l) }\end{array}$ & $5.80-11.20$ & $6.44-10.67$ \\
& 16.21 & 17.53 \\
& $6.63-29.00$ & $6.41-63.99$
\end{tabular}

\section{DISCUSSION}

The aim of the study was to assess whether the sudden change in blood glucose concentration in healthy subject would produce insulin secretory pattern similar to one in T2D subjects. The concept of the study was to "reset" the pancreas and empty the stored insulin pool, so that subtle derangements of the pulsatile insulin secretion could be studied. The increased blood glucose concentration would also increase the insulin pulse amplitude, thus making small amplitude pulses more amenable to detection.

This study showed that in the healthy subject the sudden increase of blood glucose produces insulin secretory pattern similar to the one in T2D subjects. However, the blood glucose concentration was significantly lower in the healthy subjects and it rapidly returned to normal level, while the blood insulin concentration was not different between the groups. Similar patterns of the insulin secretion in the healthy and the T2D subjects after the blood glucose increase could be explained by the exhaustion of the immediately secretable insulin pool, or by the improved detection of the low amplitude pulses due to increase in insulin pulse amplitude, or by both mechanisms operating simultaneously. 
It is known that oscillatory insulin secretion is altered in the T2D, and in the insulin resistant states $(3,4,5,6)$. However, an increase in insulin sensitivity, or the overnight inhibition of insulin secretion leads to normalisation of the insulin secretory pattern in these setting $(7,8)$. Normalisation of the insulin secretory pattern is probably caused by the repleating of the immediately secretable insulin pool (7). Therefore, the glucose bolus would deplete the stored insulin pool and make the secretory state in the healthy and the T2D subjects similar. This would manifest as the similar pattern of the oscillatory insulin secretion, as shown in this study.

The other possibility for the change in pulsatile insulin secretion is an increase in insulin pulse amplitude caused by the sudden hyperglycaemia. It was suggested that the cause of the altered plasma insulin pattern could be due to the lowering of amplitude of insulin oscillations rather then the alterations in their frequency $(9,10)$. In this study, the sudden blood glucose increase caused increase in insulin concentrations to the same level in both groups, amplifying the insulin pulse amplitudes, and making comparable conditions for the pulse detection. However, previous study did not show the change in pulse frequency or interpulse interval in T2D subjects, after the repletion of the immediately secretable insulin pool, although the insulin concentration and insulin pulse mass increased (7). Therefore, the increase in pulse amplitude and improved detection is a less probable cause of the change in the oscillatory insulin secretion pattern.

It can be concluded that the sudden increase in blood glucose causes insulin secretory pattern to become similar in the healthy and in the T2D subject. However, the defect in the insulin secretion or glucose sensing inherent to $\beta$-cell exists, as the insufficient quantity of insulin is secreted in response to the increased glucose level.

\section{REFERENCES}

1. Lang DA, Matthews DR, Peto J, \& Turner RC. Cyclic oscilations of basal plasma glucose and insulin concentrations in human beings. The New England Journal of Medicine 1979 301 1023-1027.

2. Stagner JI, Samols E, \& Weir GC. Sustained oscillations of insulin, glucagon, and somatostatin from the isolated canine pancreas during exposure to a constant glucose concentration. Journal of Clinical Investigation 198065 939-942.

3. Lang DA, Matthews DR, Burnet M, \& Turner RC. Brief, irregular oscilations of basal plasma insulin and glucose concentrations in diabetic man. Diabetes 198130 435439.

4. O'Rahilly S, Turner RC, \& Matthews DR. Impaired pulsatile secretion of insulin in relatives of patients with non-insulin dependent diabetes. The New England Journal of Medicine 1988348 1225-1230. 
5. Schmitz O, Porksen N, Nyholm B, Skjaerbaek C, Butler PC, Veldhuis JD et al. Disorderly and nonstationary insulin secretion in relatives of patients with NIDDM. Am.J Physiol. 1997272 E218-E226.

6. Zarkovic M, Ciric J, Stojanovic M, Penezic Z, Trbojevic B, Drezgic M et al. Effect of insulin sensitivity on pulsatile insulin secretion. Eur.J Endocrinol. 1999141 494-501.

7. Laedtke T, Kjems L, Porksen N, Schmitz O, Veldhuis JD, Kao PC et al. Overnight inhibition of insulin secretion restores pulsatility and proinsulin/insulin ratio in type 2 diabetes. Am.J.Physiol Endocrinol.Metab 2000279 E520-E528.

8. Zarkovic M, Ciric J, Penezic Z, Trbojevic B, \& Drezgic M. Effect of weight loss on the pulsatile insulin secretion. Journal of Clinical Endocrinology and Metabolism 200085 3673-3677.

9. Opara EC, Atwater I, \& Go VL. Characterization and control of pulsatile secretion of insulin and glucagon. Pancreas 19883 484-487.

10. Lin JM, Sternesjo J, Sandler S, \& Bergsten P. Preserved pulsatile insulin release from prediabetic mouse islets. Endocrinology 1999140 3999-4004.

11. Peiris AN, Stagner JI, Vogel RL, Nakagawa A, \& Samols E. Body fat distribution and peripheral insulin sensitivity in healthy men: role of insulin pulsatility. Journal of Clinical Endocrinology and Metabolism 199275 290-294.

12. Marchetti P, Scharp DW, Mclear M, Gingerich R, Finke E, Olack B et al. Pulsatile insulin secretion from isolated human pancreatic islets. Diabetes 1994 43 827-830.

13. Hunter SJ, Atkinson AB, Ennis CN, Sheridan B, \& Bell PM. Association between insulin secretory pulse frequency and peripheral insulin action in NIDDM and normal subjects. Diabetes 199645 683-686.

14. Porksen N, Hussain MA, Bianda TL, Nyholm B, Christiansen JS, Butler PC et al. IGF-I inhibits burst mass of pulsatile insulin secretion at supraphysiological and low IGF-I infusion rates. Am.J Physiol. 1997272 E352-E358.

15. American Diabetes Association: clinical practice recommendations 1996. Diabetes Care 199619 Suppl 1:S1-118 S1-118. 